Windle, J. (2013). 'Harms Caused by China's 1906-17 Opium Suppression

Intervention'. International Journal of Drug Policy, 24(5): 498-505. Pre-print copy.

\title{
Harms Caused by China's 1906-17 Opium Suppression Intervention
}

James Windle, School of Law, University of East London

Key words: Opium; China; Forced eradication; Drug law enforcement

\begin{abstract}
Between 1906 and 1917 China (under the Imperial and then Republican regimes) enacted a highly effective intervention to suppress the production of opium. Evidence from British Foreign Office records suggest that the intervention was centred, in many areas, upon a highly repressive incarnation of law enforcement in which rural populations had their property destroyed, their land confiscated and/or were publically tortured, humiliated and executed. Crops were forcefully eradicated and resistance was often brutally suppressed by the military. As few farmers received compensation or support for alternative livelihood creation the intervention pushed many deeper into poverty. Importantly, the repressive nature of the opium ban appears to have been a contributing factor to the fragmentation of China, highlighting the counter-productivity of repressive interventions to reduce drug crop production.
\end{abstract}




\section{Introduction}

Between 1906 and 1917 China (under the Imperial and Republican regimes) enacted a highly effective intervention to suppress the production and consumption of opium. Historian Mary Clabaugh Wright (1968: 14) pronounced the intervention as 'the largest and most vigorous effort to stamp out an established evil': a quote often reproduced when discussing the intervention (see Adshead, 1984; Forge, 1974). This article revisits the national intervention by analysing its impact upon opium farming communities. While the intervention was a 'comprehensive attack on the whole opium complex from growers to smokers' (Adshead, 1984: 71), this paper concentrates solely on the attention directed at opium farmers.

Evidence from British Foreign Office (FO) observers suggest that local interventions were centred upon a highly repressive incarnation of law enforcement, in which rural populations had their property destroyed, their land confiscated, and/or were publically tortured, humiliated and executed. Crops were forcefully eradicated and resistance was often brutally suppressed by the military. As few farmers received compensation or support for alternative livelihood creation the intervention pushed many deeper into poverty.

The brutality of the techniques used to enforce the opium ban, identified in this paper, remain underemphasized by contemporary accounts. This paper will, therefore, go some way to rectifying a blind spot in the literature by analysing new evidence, collected from documents archived at the British National Archives, from the perspective of the harm's done to opium farming communities.

It is not the authors' intention to attribute blame, but rather to add some balance to the history of drug control in China. This has much contemporary significance. The case study provides some insight into the dangers of failing to consider the impact on opium farming 
communities when suppressing drug crops. Inhumane interventions can be politically destabilising which can, in turn, inflate drug crop production.

The documents used include reports by British FO officials. These reports were often the outcome of joint-investigations conducted by both British and Chinese officials. Reports from Chinese administered anti-opium societies and English translations of official Chinese regulations were also used. The reports of FO officials and anti-opium societies are based upon a mixture of direct observations and information gathered from informants. The informants included religious missionaries and journalists, themselves well situated for direct observation.

It is accepted that there may be some bias in British FO accounts: all archived documents are shaped by the political, moral and ideological context of the time (Scott, 1990). It is also possible that British and Chinese observers may have recorded, perceived or evaluated events differently from each other. The level of divergence between British and Chinese accounts may, however, have been limited by FO observers being joined in their fieldwork by Chinese officials and the utilisation of Chinese informants.

Furthermore, Marc Trachtenberg (2007: 147; see also Tosh, 2010) has suggested that closed or restricted government documents (which later become open-archival) that survive are 'far and away the best source there is'. Privacy allows authors to express themselves more freely than they would in public. Therefore, closed and restricted documents tend to be more reliable and less distorted than published documents, and as such can:

... normally be taken as genuine ... Documents, after all, are generated for a government's own internal purposes, and what would be the point of keeping records if those records were not meant to be accurate? It's just 
hard to believe that a major goal ... would be to deceive historians thirty years later (Trachtenberg, 2007: 147).

Additionally, a number of influential studies into Chinese opium markets have relied primarily (Adshead, 1966, 1984; Newman, 1995; Spence, 1975) or partially (Reins, 1990; Wyman, 2000) on archived English language sources. This said, the author sees this paper as a first step in investigating the abuses committed in the name of drug control in China. Future research might triangulate the findings of this paper with archival Chinese sources, and/or evidence generated from other foreign observers. By doing this a more complete picture may be established, one which limits the potential distortions inherent in any set of documents created and stored by political organisations.

\section{Recent narratives on the 1906-1917 intervention}

Following the tradition of Mary Clabaugh Wright (1968: 14), much of the contemporary literature on the 1906-17 intervention begins with an elucidation of its drug control success. Consider some of the following:

It brought about quick, impressive results that proved the initial scepticism of the British and other Western diplomats wrong (Bianco, 2000: 292).

The outcomes of the first years were impressive, and eradication seemed highly probable by the time the dynasty collapsed (Paulès, 2008: 233). 
The outcome of the Qing anti-opium plan rapidly became spectacular: a very considerable decrease in both opium production and consumption took place, and on the eve of the 1912 Revolution, according to even formerly highly sceptical Western witnesses, opium was close to complete eradication (Paulès, 2008: 235).

Beginning in late 1906, it had by the end of 1908 succeeded in markedly curtailing the cultivation and consumption of opium at home and in obtaining formal assurance from the British to terminate gradually opium imports. These startling achievements are further magnified when we consider the setting within which they occurred (Reins, 1991: 101).

In terms of drug, or crime, control the intervention was undoubtedly successful: it is one of only a handful of major opium producing states to have successfully removed opium production from their national territory. If the intervention were administered today, however, there would be significant moral outrage. The effectiveness of the intervention would not nor should not - detract from the widespread harms caused to opium farming communities.

As such, words such as 'startling achievement', 'spectacular', 'impressive', and even 'successful' should be avoided, or at least followed by a strong caveat on the abusiveness of the intervention. An additional reason to avoid too much celebration is that the intervention factored in the eventual fragmentation of China, which, in turn, factored in increased opium production after 1917. This is not to suggest that the authors cited above, or below, would support the abusive treatment of farmers, nor is it an indictment of their scholarly contribution. Instead, it is hoped that this analysis of new evidence from an alternative 
perspective will be taken as a compliment to their work and help inform future research on the history of opium in China and drug control more generally.

While several authors have indicated some level of abuse, none have highlighted the extent. Thomas Reins, for example, uses British FO records to indicate how the governorgeneral of Yunnan-Kweichow 'under-took opium suppression with a vengeance' (Reins, 1991: 128). 'Vengeance' is, however, left undefined and thus open to individual interpretation. Judith Wyman (2000: 221) has indicated how law enforcement in Sichuan Province ranged from 'moral persuasion to heavy fines to corporal punishment', including on the spot strikes with a bamboo cane ('bambooing') for unregulated opium den keepers.

Lucien Bianco (2000: 306; see also Adshead, 1984), suggests that the majority of officials felt that immediate forced eradication was 'too stringent'. This may well have been the case, especially as evidence suggests that officials were coerced into mistreating farming communities by a combination of rewards and threats of punishment. Accounts described below, however, suggest that many officials were willing to put aside their reservations and administer interventions which went beyond the forced eradication of crops. Bianco (2000) does, however, highlight the economic damage that forced eradication placed upon the farmer by describing how several farmers completed suicide or violently confronted eradication teams.

Joyce Madancy (2001: 441) provides an account closer to the nature of the intervention described in British FO accounts. Madancy begins by suggesting that after the 1911 Revolution the intervention 'became increasingly coercive as opium farmers resisted efforts to uproot their crops'. While 'coercive' could be interpreted as an intervention centred upon law enforcement and does not necessarily equate abuse, a later sentence describes how it increasingly 'became difficult to distinguish genuine popular antipathy toward opium from a general tolerance of official policy or fear of state repression'. This is followed by a 
description of a magistrate who ordered that an entire village be torched for violently opposing opium suppression (Madancy, 2001: 458). This account is more intone with the evidence presented below. This said, as abuse remains a minor element of the study, Madancy's account falls short of illustrating the widespread nature of the harms caused to opium farming communities through physical punishments and economic insecurity.

Madancy is correct that the intervention became more 'coercive' after 1911. Increased repression may have had an element of a new regime asserting its authority, or it may have been a response to higher-levels of resistance to prohibition in many areas after the 1911 Revolution (FO, 1913a, 1913b). For example, a British official noted how one year after the Revolution Hunan Province undertook 'the severest repressive measures yet recorded against the opium trade' (Giles, 1913: 3). Nonetheless, as shall be highlighted below, the level of abuse had increased from a highly repressive foundation. The following section provides a historical context of opium in China. This will be followed by the presentation of evidence of the harms caused to opium farming communities collected from archived FO records. The paper concludes by reviewing the counter-productiveness of the intervention.

\section{Context}

In 1799, an Imperial edict was issued in China prohibiting the importation of opium. The British East-India Company (the source of the majority of opium consumed in China) responded by cosmetically dissolving responsibility for the trade by forbidding its employees from exporting opium. Indian opium, however, continued to be produced and packaged specifically for the Chinese market and sold at auction to private merchants who shipped to China, where corrupt officials or professional smuggling networks facilitated illicit importation (Windle, 2012). While the trade in opium was not placed under international 
regulation until 1912, and was at the time routine practice engaged in by many Western and Asian states, it was a violation of Chinese law (Windle, forthcoming). ${ }^{1}$

In 1833, the British colonial government in India increased the area under cultivation and removed a 4,000 chest $^{2}$ cap on exports to China. These changes significantly increased exports of Indian opium to China. This reduced prices and increased availability; consequently inflating Chinese consumption and the outflow of silver. This, in turn, deflated the Chinese economy and increased domestic opposition to the trade. China banned opium imports, which subsequently ignited the first 'Opium War' (1839-42). The conflict was ended by the ratification, in 1842 , of the Treaty of Nanking. There was, however, no mention of opium in the Treaty, which centred upon opening China to Western commerce and diplomacy, including forcing China to cede Hong Kong and compensate for damages done to British opium merchants. The Treaty was the first of the so-called 'unequal treaties'; meaning that China made nearly all of the concessions, the British made few, and China was forced to deal with Western powers on Western terms. ${ }^{3}$ The illicit trade continued as before; albeit at an increased level (Brook and Wakabayashi, 2000; Farley, 1977; Wakeham, 1977; Windle, 2012). By the 1830s there were an estimated two (Zhou, 1999) to three million (McCoy, 2003) consumers of opium in China.

In 1858, the Chinese government - after fighting a Second 'Opium War' (1856-60) with the British and French - legalised the importation of opium by including it on a list of goods subject to import tariff. Much like the Treaty of Nanking, there was no mention of opium in the Treaty of Tianjin, ratified in 1860 to end the Second Opium War. The Treaty again centred upon opening China to Western powers, including allowing British ships to enter

\footnotetext{
${ }^{1}$ The Chinese prohibition was one of a number of prohibitions enacted in Asia during the 17th, 18th and 19th centuries. All of which were later undermined by Western traders (Windle, forthcoming).

${ }^{2}$ One chest contained 63.5kg (Pietschmann et al, 2009).

${ }^{3}$ The Treaty is still seen in China as a prime example of foreign imperialist exploitation (Wakeham, 1977; Zhou, 1999).
} 
Chinese sovereign waters in pursuit of pirates (Spence, 1990). The legalisation of opium imports came about through a series of negotiations between China and the major Western powers on the import tariffs of various commodities. Under significant pressure, China agreed with the American and British proposal of imposing an import tariff on opium (Lazich, 2006): thus overturning the long held prohibition on the importation of opium.

After import legalisation, China approved the taxation of opium production in Yunnan Province to fund the suppression of the Panthay Uprising. Several other provinces followed this example and de facto legalisation preceded the official repeal of prohibition in the mid1880s. After which many provinces encouraged the production of opium and, importantly, improved the quality of opium being produced. By 1905 China produced eight times more than was imported: Sichuan and South-West Hupei Provinces together produced eight times that of India, which remained China's primary, although not only, foreign opium source (Windle, 2011, 2012). ${ }^{4}$ Almost all opium was consumed within China, although a small amount was exported to French Indochina (FO, 1913c).

Low prices and profuse availability increased consumption to exceptionally high levels. In 1890, an estimated 10 percent of the Chinese population smoked opium (Spence, 1975); this may have been as high as 50 (Adshead, 1984), 60 or 80 percent in some areas (Spence, 1975), while as low as five percent in others (Newman, 1995). By 1906 official Chinese accounts suggest that between 30 to 40 percent of the population had smoked opium (FO, 1907). This said, the majority appear to have consumed small quantities and avoided heavy or habitual use (Dikötter et al., 2004; Newman, 1995).

While opium provided the state with extensive revenues (Jordan, 1908; Windle, 2012), it was increasingly perceived as a barrier to economic and military advancement as well as a threat to national health (Baumler, 2000; Walker, 1991). Additionally, external barriers to

\footnotetext{
${ }^{4}$ China also imported opium from Persia and Turkey (Windle, 2012).
} 
prohibition were weakened at the beginning of the twentieth-century when British opposition to prohibition softened and America began lobbying for stricter global controls (Brook and Wakabayashi, 2000; Windle, 2012).

The British decision to remove its long standing opposition to Chinese prohibition was the result of a convergence of moral, economic and political concerns. The economic importance of opium to the British administration in India had declined significantly during the late-19th century (Windle, 2012). Additionally, there had been a gradual shift in the perception of opium in the UK from a relatively harmless drug to be tolerated, towards one of opium as a threat to health and, thus, something to be prohibited. Furthermore, moral entrepreneurs, many of whom had been working in China as missionaries, had been pressurising the British government to support China's prohibition. Similar economic, political and moral pressures had moved America to convene the First International Opium Commission in Shanghai in 1909 (Windle, forthcoming). The Commission was centred largely on a multilateral agreement to support China in its prohibition (Pietschmann et al, 2009).

\section{The intervention}

In September 1906, China issued an Imperial Decree declaring the gradual suppression of opium production, trade, and consumption. This was followed by the 'Regulations Giving Effect to the Imperial Decree' which obliged provincial governors to: produce estimates of the area under cultivation, license and meticulously monitor farmers, annually reduce the area and number of farmers by one-ninth, and confiscate land used by unlicensed farmers. Rewards for governors which ended production prematurely were also provided for (FO, 1907). Two months after the enactment of the Regulations governors were ordered to halve the area under cultivation within two years (International Anti-Opium Association, 1924). To 
reduce the economic shock to provincial economies, land and transport taxes were increased (FO, 1911a), as were taxes on opium just prior to the enforcement of bans (Adshead, 1984).

Once the ban was enforced, China negotiated the 1908 'Anglo-Chinese Ten-Year Suppression Agreement'. The Agreement obliged British administered India to annually reduce exports to China by ten percent and China to concurrent reductions in production. China agreed to allow British consulates to monitor progress (Dixon, 1922).

The subsequent 'Prohibition on Opium' (reproduced in Leech, 1908) ordered provincial governors to have banned and suppressed all production by $1915 / 16$. This was followed by the 1911 'Anglo-Chinese Opium Agreement' which stipulated that any province proving to a Joint British-Chinese Commission of Investigation (henceforth Joint Investigation) that they were 'opium-free' could prohibit the importation of Indian opium. 'Opium-free' was defined as any province which 'effectively suppressed the cultivation ... of native opium' (reproduced in FO, 1915a: 1). British FO employees stationed in China were thus tasked with observing China's legal commitment to suppression. Joint Investigation consisted of direct observations by Chinese and British officials touring opium producing areas. British officials supplemented this with information from the local media, religious missionaries, local antiopium groups and other informants.

As can be expected from a state twice the size of Europe the campaign progressed unevenly across and within provinces (Adshead, 1984; FO, 1910a; Hosie, 1909; Wyman, 2000). While conformity was slower in major producing provinces, by mid-1910 all provincial leaders had succumbed to pressure and the ban was stringently enforced (FO, 1910c; see also Adshead, 1984; Forges, 1973). By 1911 many provinces had already been declared 'opium-free' by Joint Investigation and national production had declined by 89 percent: from an estimated 35,353 tonnes (Jordan, 1913) in 1906 to 4,000 tonnes in 1911 (Pietschmann et al., 2009). 
The national intervention was, however, obstructed by the removal of the Imperial regime in the 1911 Revolution. While there was an initial resurgence during the revolutionary period (Central China Post, 1912) production remained below 1906 levels (Jordan, 1913). Then, in 1912, the new regime ordered all officials to renew suppression efforts (Walker, 1991). Joint Investigations resumed (Cheng, 1913; Grey, 1913). British FO accounts suggest that the new Republican regime initially surpassed 'the rigors of the Manchu rulers' (Dixon, 1922: 2) and a:

... general survey of the whole evidence leads to the conclusion that with the exceptions of Kweichow [Guizhou].... the authorities throughout the Republic are making strenuous efforts (Jordan, 1913: 13).

By 1913, half of all provinces had been declared 'opium-free' by Joint Investigation (Eisenlohr, 1934; FO, 1913d). By the end of 1917 China was declared 'opium-free' in its entirety after a comprehensive investigation by a Joint British-Chinese Commission (Foreign Policy Association, 1924). The fragmentation of the state from late-1916 was, however, to make prohibition unsustainable (Windle, 2011).

From 1911, numerous warlords had begun consolidating their authority separate from Beijing. In 1915, several warlords from Yunnan Province declared their independence. This example was followed by several other provinces. Then, in June 1916, the Republican President, Yuan Shikai, died. Responding to this opportunity, the majority of southern warlords declared independence whilst northern warlords fought for authority over the central government in Beijing; fragmenting the Chinese state (Spence, 1990; Wakeham, 1977; For analysis of post-1916 production see Windle, 2011). 
While suppression officially continued in areas under Beijing authority - just two or three provinces around the capital - control of the central government was unstable and composed of belligerent northern warlords (Bianco, 1967). One British consulate reported the futility of approaching the impotent central government to protest against increasing production (Dixon, 1922). Especially as many warlords facilitated opium production to finance conflicts over territories, the central government, and/or areas important to the profitable opium trade (Bianco, 2000; FO, 1920; International Anti-Opium Association, 1924). While some local power-holders coerced farmers into growing opium at the expense of food crops (see Windle, 2012), in others opium was profitable enough that farmers chose to side with warlords and openly resisted bans imposed by civil governments (Bianco, 2000). As will be discussed in greater length later in this paper, it is possible that the physical punishments and economic insecurity caused by the suppression of opium farming may have factored in the eventual removal of the Imperial Regime in 1911, the fragmentation of the state in 1916 and the ascension to power of some warlords. As opium production increased during this period of instability, the harms caused by the intervention may have been counterproductive to drug control objectives in the long-term.

The remainder of this section shall discuss the methods employed in the 1906-17 intervention. The intervention can be split into four broad and overlapping constituent parts: disincentives, incentives, punishment of officials, and responses to resistance.

\section{Disincentives}

From 1911, the official punishment for opium farming was one to three years imprisonment and the confiscation of land (Changsha Jih Pao, 1911; FO, 1913e). Nonetheless, forced eradication appears to have been a favoured practice. Under both the Imperial and 
Republican regimes farmers were either compelled by the military to eradicate their own opium poppies or had their crops destroyed by eradication teams (Hosie, 1912; FO, 1911b, 1913f, 1913g). For example, in Shantou Prefecture farmers were ordered by the magistrate to eradicate their own crops within five days or face military punishment. After which a group of soldiers toured the villages forcefully eradicating opium poppies (FO, 1913e, 1915b). There are also multiple accounts of the administration of significantly harsher punishments. In Yunnan Province, for example, the magistrate issued the following regulation in 1913:

Any person found cultivating the poppy will have his land confiscated: it matters not whether the land is his or rented from another. Such person will in addition be sentenced to ten years imprisonment without the option of a fine. Any person resisting this regulation or refusing to root up the poppy when order to do so will be publically shot in accordance with military law (FO, 1913m: 2).

In practice, punishments - often enforced by the provincial police and military - for cultivation and/or resistance during both Imperial and Republican interventions could include a mixture of the following: fines, the seizure or destruction of property, public shaming, corporal or capital punishment. One British observer noted how 'the sacrifice of lives and property' was 'no obstacle' (FO, 1913d). There is one description of soldiers beating farmers to extract information in Zhejiang Province (FO, 1913h), whilst another British official observed: 
... crops were uprooted and trampled on; men were beaten senseless by the roadside in the midst of their ruined fields; the job was done with a savage thoroughness which defies parallel (Contemporary Review, 1922: 466).

Alexander Hosie, a British consul, remarked of the intervention in Yunnan Province: 'the cultivators were so heavily punished it is unlikely that such offences will recur' (Hosie, 1910a: 166). Similarly in 1913, the British consulate in Hunan noted that the intervention 'has been accompanied by cruelty and corruption' (FO, 1913i: 151). Consider the following observations:

From 1914 to 1916 poppy cultivators in the country districts [of Jiangxi Province] have been harried by officials, gentry and soldiers. Oppressed, fined, imprisoned, their land confiscated, and their homesteads burnt, and their lives imperilled, opium growers have come to the conclusion that the government was in earnest and that the cultivation of the poppy was too costly and dangerous an undertaking (FO, 1917a: 283).

Near Shen-chou-fu [Hunan Province] popular feeling was running high in consequence of the massacre of an entire family including women and children. In a neighbourhood district sixty-seven farmers, who had offered a successful resistance to the soldiers, were surrounded in a temple which was burned over their heads, and from which none escaped (FO, 1913i: 151). 
Farmers refusing to eradicate their own crops in a district of Jiangxi Province were 'in some instances shot, in others their houses were burnt and their land confiscated' (FO, 1917b: 284). While in Shantou Prefecture, farmers were given five days to uproot all opium poppies. After the time frame had elapsed the magistrate toured with 60 soldiers, eradicating all opium they came across. In at least one case the soldiers burnt the 'field watchers' hut, confiscated farmland and eradicated all opium poppies (FO, 1913e). In another case, reported in 1910, an entire village was demolished (FO, 1910a; destruction of property was also reported in: FO, 1913e, 1913g; Turner, 1914).

A Joint Investigation by British and Chinese officials in Shantung Province observed:

... I saw the Chi Chia Chung poppy grower being dragged through the streets handcuffed, a chain around his neck, and on his back a placard describing his offence. I was told that he had been sentenced to ten years imprisonment and to 4,000 blows from the light bamboo (FO, 1913j; canning is also reported in FO, 1909a).

An opium dealer was similarly punished with public humiliation by being placed in a cage and paraded around the streets (FO, 1909b). While in:

Changlo [Hupei Province] a man on whose ground two or three plants were found was sentenced to death, but at the last moment his sentence was moderated, and he was branded and led through the town and adjoining districts loaded with chains (FO, 1914a; public humiliation is also reported in FO, 1910a). 
In Fujian Province the Joint Investigation described a magistrate who, being a 'little too vigorous', had arrested and fined farmers, confiscated their land, and burnt their houses. He then beheaded any which 'received these corrections with ill grace' (Turner, 1914: 3; also FO, 1914b).

There are multiple mentions of opium farmers being executed for refusing to uproot their crops or for replanting after the initial eradication (Central China Post, 1912; FO, 1913h; Scheltema, 1910; Taylor, 1913). For example, 20 people were executed in Wen-shui-Hsien District (Hosie, 1910b), eight were shot in Lo K'ou District (FO, 1917b) and in Hupei Province:

... the magistrate recently returned from a trip in his district and brought back four prisoners charged with cultivating poppy, and they were all shot (FO, 1914c: 1).

In Changsa District, the magistrate ordered that anyone caught sowing opium would be 'shot without mercy' (FO, 1913k: 39). At the extreme, an entire village was massacred as a warning to Yunnanese farmers (FO, 19131) and a 'few hundred' farmers were executed in Shanxi Province (FO, 1917c: 3). While in Hunan Province, 46 were executed for consuming and cultivating opium (Giles, 1913). While the majority of those put to death were shot, there are at least two reports of beheadings (FO, 1914b; Turner, 1914). As it was believed that the degradation of the body would continue into the next life, beheading represented an additional cruelty (Brook et al., 2008).

Corporal punishment was extended to gentry who permitted - or did not attempt to suppress - opium cultivation in their sphere of authority. For example: 
... at Tsingchow the determination of a zealous magistrate who made an official tour through his district, flogging local gentry where the poppy was found, has had a beneficial effect (FO, 1910a: 2).

While in Guizhou Province a district governor declared that the head men of villages growing opium would be punished (FO, 1913f). There are also reports of farmers being executed for failing to report neighbours to the authorities (FO, 1917d).

Even milder punishments provided significant damage. Many opium farmers, or entire villages, were fined (FO, 1910c) and then had their fields confiscated. The fields would then be sold back to them. As many farmers could not afford to re-buy many became 'overgrown with weeds' (Turner, 1914: 124). The financial pressure of confiscation must have been hugely damaging to resource deficient farmers. For example, in $\mathrm{Yu} \mathrm{Tu}$ District (Jiangxi Province) 'such heavy fines were inflicted by the former magistrate that the offenders were forced to sell their children' (FO, 1917b: 284). ${ }^{5}$

\section{Incentives}

In 1911, to motivate crop substitution, the Chinese financial commissioner relieved all farmers growing cereals of land tax for a year and a half. While this stimulated some provinces to experiment with foreign cereals (Chengsha Jih Pao, 1911), no 'serious attempt' was made to provide alternative incomes. As such, many farmers were pushed deeper into poverty and provincial government budgets were depressed (International Anti-Opium Association, 1922: 21; FO, 1910b; Rose, 1910). The lack of state support is exemplified by

\footnotetext{
${ }^{5}$ The sale of children to pay off debts created by opium bans has been reported in contemporary Afghanistan (Ahmadzai and Kuonqui, 2011; Mansfield, 2004).
} 
crop substitution being mentioned just 12 times in the 472 FO reports consulted (although not necessarily cited) by this author. One reports how a district in Sichuan Province provided no support (FO, 1910b), whilst another recounts how, due to inactivity by the provincial government of Yunnan, a British diplomat introduced improved cotton from India (Rose, 1910). Substitute crops were provided by local governments in four provinces (FO, 1908, 1913b, 1914a; Rose, 1913; Turner, 1914; Wilkinson, 1910; Wyman, 2000) and some farmers were compensated in Yunnan. The viceroy of Sichuan experimented with imported American cereals and taught farmers improved agricultural methods (FO, 1909a), although there was no substantial provision for developing alternative crops (Adshead, 1984).

One British official noted how the lack of alternative incomes and increasing impoverishment made prohibition unpopular with the majority of Chinese farmers. Whilst the outflow of silver to pay for illicitly imported opium made it unpopular with officials. This was especially pertinent for provinces such as Yunnan which possessed few exportable commodities (Rose, 1910; see Adshead, 1984). The official insightfully concluded that at:

... the first sign of relaxation in ....[the] attitude towards the opium question would assuredly be the signal for the poppy to spring up throughout the miles of territory now lying fallow for want of capital and knowledge and suitable crops (Rose, 1910: 34).

It is likely that the severity of punishments discussed above differed between and within provinces. It is also possible that less abusive, and therefore more mundane, opium bans went unrecorded by British observers. This said, the imposition of opium bans without the provision of alternative sources of income was in itself extremely harmful, regardless of the infliction of physical punishments (for contemporary examples of harms caused by banning 
opium without the provision of alternative incomes see Mansfield and Pain, 2006; Youngers and Walsh, 2010).

\section{Punishment of officials}

The 'Regulations Giving Effect to the Imperial Decree' provided rewards for governors which ended production prematurely. In addition to rewards, in many provinces, officials were punished for failure to suppress the production of opium (FO, 1910c). For example, while officials in eastern Sichuan expressed a degree of apathy for prohibition, the perception that efficient suppression would assist their career advancement meant that many undertook their orders in a zealous manner (FO, 1910b; also FO, 1913e, 1915c; Spence, 1990). In Anhui Province the governor dismissed a district magistrate for failing to reduce opium cultivation quickly enough, while other officials had their pay withheld (FO, 1910c, 1913e). Hence, fear of failure instilled a motivation to thoroughly enforce prohibition. While production bans were intended to be gradually introduced, the linkage of prohibition to career advancement quickened the pace of bans. This may, in turn, have influenced decisions to use repressive measures.

\section{Violent resistance}

British FO records provide several instances of violent resistance to eradication, before and after the 1911 Revolution. State responses to violent opposition resulted in significant loss of life and perpetuated the abuse of farmers (see FO, 1911b, 1912, 1913a, 1913b, 1913k, 1915b; Hosie, 1910a). For example, a Joint Investigation in Hunan Province reported: 
The [provincial] authorities themselves claimed that 200 farmers had lost their lives in the Chien-chou prefecture alone in the attempt to defend their crops from destruction, and we had independent news of skirmishes and loss of life in almost every district along the Kweichow [Guizhou] border (FO, 1913i: 151).

In Sichuan Province, the leader of a 'secret society' established to protect farmers was beheaded after a battle with a battalion of soldiers (FO, 1910b) while, in a separate incident, 118 farmers were killed by soldiers suppressing a riot (Adshead, 1984). In Shanxi Province, 20 farmers were killed and 30 were wounded by belligerent soldiers (Hosie, 1910b). In a district of Shantou Prefecture the magistrate ordered the arrest of a landlord for facilitating opium cultivation. When the soldiers sent to arrest him were attacked by villagers, the magistrate returned with a 'machine gun battalion' and 280 soldiers: fifty farmers and soldiers died in the subsequent conflict (FO, 1913e). In another example, the army executed 18 members of an 'opium farmer's union' before eradicating the village's opium poppies (FO, 19131: 36).

\section{The counter-productivity of repressive interventions}

This case study is an extreme example that highlights an important point of contemporary interest: Drug crop suppression interventions which present significant harm to farming communities are likely to be ineffective in the long-term (and often contrary to current international human rights norms, for contemporary examples see Barrett and Nowak, 2009). The majority of states which have successfully suppressed or significantly reduced the production of opium in their territory have done so by extending the state into formerly geographically and socially isolated territories (i.e. Thailand, Laos, Viet Nam). As this state 
extension can be hindered by policies which further alienate and anger opium farming communities, harmful interventions can be counter-productive. Even relatively repressive interventions, such as those imposed in China during the 1950s, presented farming communities with some incentive to comply: The intervention came about after the removal of an unpopular regime in a revolution which professed to place rural communities at the centre of agricultural and social reform (Windle, 2011).

The case of Imperial/Republican China is illustrative for its inability to sustain suppression. The intervention was, at least in the localities described above, repressive and failed to provide farmers with sufficient alternatives to opium. There is some evidence to suggest that the intervention weakened the Imperial regimes' authority in (ex-)opium producing areas. A similar resentment may have been felt for the Republican regime. For example, according to Samuel Adshead (1966: 92; 1984), opium suppression in Sichuan Province resulted in negative 'structural alterations of the first magnitude' which undermined the provincial government, both economically and politically. One of the unintended consequences of the intervention being that farmer's discontent with their treatment was a factor in the significant number of rural peoples lending their support for the 1911 Republican revolution (Adshead, 1966, 1984). It is likely that when the state fragmented in 1917 many disgruntled farmers provided their support to warlords, and other local power holders, promising the repeal of prohibition. This parallels experiences in contemporary Afghanistan.

In 2000 the Taliban, as rulers of Afghanistan, enforced an opium ban which reduced the area under cultivation by 91 percent (UNDCP, 2001). Sources have suggested that the intervention was 'inhumane and draconian' with local community leaders ordered to forcefully eradicate crops and punish farmers. Many community leaders unable or unwilling to suppress the crop were themselves punished. Recorded punishments included public humiliation, imprisonment, flogging and execution (Farrell and Thorne, 2005; Moore, 2002). 
Furthermore, the general brutality of the Taliban regime was sufficient for farmers to accept orders and cease opium cultivation, knowing that 'severe punishment, including the destruction of property, torture and death, would await any transgressor' (McDonald, 2005: 94).

As importantly the economic impact of the ban forced many farmers and landowners to borrow money to repay debts incurred during the previous growing season. Others fled to Pakistan to avoid repaying debts or sold livestock, or in some cases children (Mansfield, 2004).

Furthermore, in several areas, the ban facilitated widespread popular resistance and weakened the Taliban's authority just prior to the American led invasion. Southern Pashtuns, for example, fought against the Taliban during the conflict, motivated 'in large part' by the ban (Felbab-Brown, 2010: 132). ${ }^{6}$

Increased production was the second unintended consequence. After the ban ended production increased dramatically. This was partly due to farmers being forced to grow greater amounts of opium to repay debts (Felbab-Brown, 2010; Mansfield, 2004; UNDCP, 2001). This is not to suggest that the mistreatment of opium farmers was the primary cause of the removal of the Imperial regime in China or the Taliban in Afghanistan. Rather it is suggested that repressive treatment and the failure to offer incentive to cease production can weaken a state's political capital (Felbab-Brown, 2010). ${ }^{7}$ This can, in turn, negatively impact state authority: the foundation of a long-term, successful, intervention.

\section{Conclusion}

\footnotetext{
${ }^{6}$ The Taliban are believed to have been aware of the threat of revolt created by the resentment towards the ban and rescinded it just prior to the invasion (Felbab-Brown, 2010; McDonald, 2005).

${ }^{7}$ Thoumi (2005) discusses how insufficient social capital was a major factor influencing Columbia's 'competitive advantage' in coca/opium trafficking.
} 
How does one account for such a rapid and effective campaign in a province [Sichuan] where the vast majority of the people had a strong vested interest in keeping the drug in circulation? (Wyman, 2000: 212).

For Judith Wyman (2000: 213; see also Adshead, 1984; Taylor, 1913), the answer lies in the 'assertive leadership of the provincial government'. While suppression would not have been possible without the support of the provincial political elite, the statement overlooks an important causal factor: the abuse perpetrated on opium farming communities. Therefore, a more nuanced explanation may read: the assertive and highly repressive leadership of the provincial government.

In terms of drug control, the intervention was highly effective. This paper has revisited the intervention by focussing on the harms caused to opium farming communities. Evidence collected from the British FO suggest that opium poppies were forcefully eradicated whilst farmers were fined, had their land confiscation, property destroyed and were subjected to public humiliation, corporal and capital punishment. Resistance was often brutally put down by the military and many farmers were driven deeper into poverty by the lack of support for alternative livelihood creation. The intervention, in short, caused significant harm to opium farming communities. If this intervention were undertaken today it would be considered, at best, a gross violation of human rights. Additionally, as repression and economic neglect of farming communities were contributing factor to the fragmentation of the state, and increased production thereafter, suppression was counterproductive in the long-term, if effective in the short-term.

This initial foray into the issue suggests widespread abuses across several parts of China. The challenge is now to identify the national extent of abuse. Future research should also 
identify whether these localised examples are the exception or the rule and, whether they were the product of a deliberate and conscious central government policy which resulted in widespread and systematic abuse.

By providing new evidence and refocusing analytical attention from drug control towards the harms caused to farmers this paper has gone some way to adding balance to an important episode in the history of China and international drug control. This paper not only highlights abuses in the name of drug control but also presents an important example of how repressive drug crop suppression interventions can be counter-productive in terms of drug policy. The case study suggests that policy makers should pay attention to the potential harms imposed upon farming communities before creating or implementing policies, whilst academic analysis must account for the impacts of interventions on farming communities.

\section{References}

Adshead, S. (1966). Opium in Szechwan, 1881-1911, Journal of Southeast Asian History, 7(2), 93-100.

Adshead, S. (1984). Provinces and Politics in Late Imperial China. London: Taylor and Francis.

Ahmadzai, A. and Kuonqui, C. (2011) In the Shadow of the Insurgency in Afghanistan: Child Bartering, Opium Debts, and the War on drugs. In D. Barrett (Ed.). Children of the Drug War. New York: Idebate Press.

Barrett, D. and Nowak, M. (2009). The United Nations and Drug Policy: Towards a Human Rights-Based Approach. In A. Constantinides and N. Zaikos (Eds.), The Diversity of International Law: Essays in Honour of Professor Kalliopi Koufa, London: Brill.

Baumler, A. (2000). Opium Control Versus Opium Suppression: The Origin of the 1935 SixYear Plan to Eliminate Opium and Drugs. In T. Brook \& B. Wakabayashi (Eds.), 
Opium Regimes: China, Britain, and Japan, 1839-1952, London: University of California Press.

Bianco, L. (1967). Origins of the Chinese Revolution, 1915-1949 (translated by M. Bell), Stanford: Stanford University Press.

Bianco, L. (2000). The Response of Opium Growers to Eradication Campaigns and the Poppy Tax, 1907-1949. In T. Brook \& B. Wakabayashi (Eds.), Opium Regimes: China, Britain, and Japan, 1839-1952, London: University of California Press.

Brook, T., Bourgon, J. \& Blue, G. (2008). Death by a Thousand Cuts, London: Harvard University Press.

Brook, T. \& Wakabayashi, B. (2000). Opium's History in China. In T. Brook \& B. Wakabayashi (Eds.), Opium Regimes: China, Britain, and Japan, 1839-1952, London: University of California Press.

Central China Post. (1912). China is Suppressing Opium. December $14^{\text {th }} 1912$. In National Archives of the UK: FO 881/10481.

Changsha Jih Pao. (1911). Extract from the Changsha Jih Pao with Reference to Opium Suppression. November $21^{\text {st }} 1911$. In National Archives of the UK: FO 228/2439.

Cheng, L. (1913). Mr Lu Cheng to Sir J. Jordan, February $13^{\text {th }}$ 1913. In National Archives of the UK: FO 881/10481.

Contemporary Review. (1922). The New Opium Problem in Western China. Contemporary Review, 122, 466-475.

Dikötter, F., Laamann, L. \& Zhou, X. (2004). Narcotic Culture: A History of Drugs in China, London: Hurst and Company.

Dixon, G. (1922). The Truth About Opium, London: India Office. In National Archives of the UK: FO 228/3365. 
Eisenlohr, L.E.S. (1934). International Narcotics Control London: George Allen and Unwin Ltd.

Farley, F. (1977). Commissioner Lin and Opium. History Today, 27(2), 73-82.

Farrell, G. and Thorne, J. (2005). 'Where Have all the Flowers Gone?: Evaluation of the Taliban Crackdown Against Opium Poppy Cultivation in Afghanistan'. International Journal of Drug Policy, 16(2), 81-91.

Felbab-Brown, V. (2010). Shooting Up: Counterinsurgency and the War on Drugs. Washington: Brookings Institute.

FO. (1907). Memorandum Respecting the Prohibition of Opium Smoking in China. In National Archives of the UK: FO 881/9099.

FO. (1908). Opium Eradication Report. In National Archives of the UK: FO. 228/2423

FO. (1909a). Opium Report for the Quarter. In National Archives of the UK: FO. 228/2426.

FO. (1909b). B.M. Consulate-General, Yunnanfu, April 6, 1909. In National Archives of the UK: FO. 228/2426.

FO. (1910a). H.B.M. Consulate-General, Hankou. (1910). Suppression. October $22^{\text {nd }}$. In National Archives of the UK: FO 228/2434;

FO. (1910b). Report on Opium Eradication in Ch'uantung (Eastern Szechwan) for the 190910 Season. In National Archives of the UK: FO 881/9892.

FO. (1910c). Chinese Reports on the Suppression of Opium Production in China in 1910. (Official Translation), in A. Hosie (Ed.), Despatch No. 6 of October 28 th 1910. In National Archives of the UK: FO 228/2434.

FO. (1911a). Consulate-General, Hankow. (1911). Opium Report for March Quarter. In National Archives of the UK: FO 228/2440.

FO. (1911b). British Consulate-General, Yunnanfu. (1911). Opium Report, March $29^{\text {th }}$. In National Archives of the UK: FO 228/2440. 
FO. (1912). Evidence of Opium Planting in Chengtu, $1^{\text {st }}$ November 1912. In National Archives of the UK: FO 228/2451.

FO. (1913a). Tabular Statement Showing Success Achieved in the Suppression of Opium Cultivation in Each District of Chuan Tung in the Province of Szechwan. In National Archives of the UK: FO 228/2455.

FO. (1913b). Memorandum on the Anti-Opium Movement in Ichang during the Quarter Ending June $30^{\text {th }}$, 1913. In National Archives of the UK: FO 228/2455.

FO. (1913c). Report on Opium in Yunnan Province, No. 7 of 1913. In National Archives of the UK: $228 / 2455$.

FO. (1913d). June $6^{\text {th }}$, 1913. In National Archives of the UK: 228/2454.

FO. (1913e). Consulate, Swatow. Opium Matters in Swatow District: Diary of Events. February $18^{\text {th }}$. In National Archives of the UK: FO 228/2453

FO. (1913f). Report on Opium Cultivation in Yunnan and Kweichow Provinces, No. 4 of 1913. In National Archives of the UK: FO 228/2453

FO. (1913g). H.B.M. Consulate, Chengtu. Opium Cultivation etc. in Szechuan. March $2^{\text {nd }}$, 1913. In National Archives of the UK: 228/2453.

FO. (1913h). Ningpo Consulate. (1913). Opium Suppression in the Ningpo Consular District. June 13th 1913. The National Archives of the UK: 228/2455.

FO. (1913i). Enclosure 2 in No.130, Report on Journey in Hunan. In National Archives of the UK: FO 881/10481.

FO. (1913j). Enclosure 5 No. 130, report on Journey in Shantung. In National Archives of the UK: FO 881/10481.

FO. (1913k). H.B.M. Consulate, Changsha. (1913). Opium Report for September Quarter, 1st October, 1913. In National Archives of the UK: 228/2456. 
FO. (19131). H.B.M. Consulate, Tengyeh. April 10 ${ }^{\text {th }}$, 1913. In National Archives of the UK: FO 228/2454

FO. (1913m). Translation: Instructions issued by the Military Governor and the Civil Administrator of the Province of Yunnan, No.489 (1913). In National Archives of the UK: $228 / 2456$.

FO. (1914a). Report on the Investigation of the Cultivation of Poppy in Hupeh. In National Archives of the UK: $228 / 2458$.

FO. (1914b). H.B.M. Consulate, Foochow. Opium Investigation in the North of Fukien. March 21st 1914. In National Archives of the UK: 228/2457.

FO. (1914). Memorandum Containing the Replies to Six Questions Which Formed the Contents of an Opium Circular Addressed to British Missionaries in the Province of Hupei. In National Archives of the UK: 228/2457.

FO. (1915a). Agreement Relating to Opium, 1911. In National Archives of the UK: FO 228 2461

FO. (1915b). Opium Suppression Notes for December Quarter, 1914.HBM Consulate, Swatow, January $8^{\text {th }}, 1915$. In British National Archives, Kew London: FO 228/2461. FO. (1915c). Poppy cultivation and Opium Traffic Forwards further notes on. In National Archives of the UK: FO 228/2461

FO. (1917a). Report on an Inspection of the Province of Kueichow. In British National Archives, Kew London: 228/2466.

FO. (1917b). Report of a Journey of Investigation into the Cultivation of the Opium Poppy in the Province of Kiangsi. In National Archives of the UK: 228/2465.

FO. (1917c). H.M. Consulate, Nanking. (1917). Poppy Cultivation in Kiangsu. $3^{\text {rd }}$ March 1917. In National Archives of the UK: 228/2454. 
FO. (1917d). Report on a Tour of Inspection for Opium in West and South Yunnan. In British National Archives, Kew London: 228/2466.

FO. (1920). H.B.M. Consulate, Foochow. Opium in Fukien. $20^{\text {th }}$ April 1920. In National Archives of the UK: FO 228/3361

Foreign Policy Association. (1924). China. Committee on Traffic in Opium. October 24th 1924. In National Archives of the UK: FO 371/10345.

Giles. (1913). Consular Giles to Sir J. Jordan. February $6^{\text {th }} 1913$. In National Archives of the UK: FO 881/10481.

Grey, E. (1913). Sir Edward Grey to Sir J. Jordan, December $8^{\text {th }}$ 1913. In National Archives of the UK: FO 881/10481.

Hosie, A. (1909). Dispatch from his Majesty's Minister in China Forwarding a General Report By Sir Hosie Respecting the Opium Question in China. In National Archives of the UK: FO 228/2423.

Hosie, A. (1910a). Despatch No. 6 of October $28^{\text {th }}$ 1910. In National Archives of the UK: FO $228 / 2434$.

Hosie, A. (1910b). Report by Sir A. Hosie on the Cultivation of the Poppy and the Production of Opium in the Province of Shansi, Shensi and Kansu. In National Archives of the UK: FO 881/9904.

Hosie, A. (1912). Report by Consul-General Sir A. Hosie on the Cultivation of the Poppy and the Production of Opium in the Province of Kueichow. In National Archives of the UK: FO $881 / 9975$

International Anti-Opium Association. (1922). The War Against Opium, Tientsin: Tientsin Press Ltd.

International Anti-Opium Association. (1924). Opium Cultivation and Traffic in China 4(2), Tientsin: Tientsin Press Ltd. 
Jordan, J. (1908). Sir J. Jordan to Sir Edward Grey. January $11^{\text {th }} 1908$. In National Archives of the UK: FO 881/9139.

Jordan, J. (1913). Sir J. Jordan to Sir Edward Grey. February $10^{\text {th }} 1913$. In National Archives of the UK: FO 881/10481.

Lazich, M.C. (2006). American Missionaries and the Opium Trade in Nineteenth-Century China. Journal of World History, 17(2), 197-223.

Leech, L. (1908). Dispatch from his Majesty's Minister in China Forwarding a General Report by Mr Leech Respecting the Opium Question in China. In National Archives of the UK: FO 248/2242.

Madancy, J. (2001). Unearthing Popular Attitudes toward the Opium Trade and Opium Suppression in Late Qing and Early Republican Fujian. Modern China, 27(4), 436-483.

Mansfield, D. (2004). What is Driving Opium Poppy Cultivation? Decision Making Amongst Opium Poppy Cultivators in Afghanistan in the 2003/4 Growing Season. Paper for the UNODC/ONDCP Second Technical Conference on Drug Control Research

Mansfield, D. and Pain, A. (2006). Opium Poppy Eradication: How to raise risk when there is nothing to lose? Afghanistan Research and Evaluation Unit. Consulted 12 November 2007. http://www.areu.org.af

McCoy, A. (2003). The Politics of Heroin, Chicago: Lawrence Hill Books.

McDonald, D. (2005). Blooming Flowers and False Prophets: The Dynamics of Opium Cultivation and Production in Afghanistan under the Taliban. International Journal of Drug Policy, 16(2), 93-97.

Moore, M. (2002). City's Crackdown Moves the Opium Market Underground. The Boston Globe, March 16.

Newman, R.K. (1995). Opium Smoking in Late Imperial China: A Reconsideration. Modern Asian Studies, 29(4), 765-794. 
Paulès, X. (2008). Anti-Opium Visual Propaganda and the Deglamorisation of Opium in China, 1895-1937. European Journal of East Asian Studies, 7(2), 229-262.

Pietschmann, T., Tullis, M. and Leggett, T. (2009). A Century of International Drug Control. Vienna: UNODC.

Reins, T.D. (1991). Reform, Nationalism and Internationalism: The Opium Suppression Movement in China and the Anglo-American Influence, 1900-1908. Modern Asian Studies, 25(1), 101-142..

Rose, A. (1910). Report by the Acting Consul Rose on the Opium Crops in Western Yunnan for the Season 1909-1910. In National Archives of the UK: FO 881/9904.

Rose, A. (1913). Mr Rose's Opium Report on Hunan. In British National Archives, Kew London: FO 228/2454.

Scheltema, J.F. (1910). The Opium Question. The American Journal of Sociology, 16(2), 213-235.

Scott, J. (1990). A Matter of Record. Oxford: Blackwell.

Spence, J. (1975). Opium Smoking in Ching China. In F. Wakeman \& C. Grant (Eds.), Conflict and Control in Late Imperial China, London: University of California Press.

Spence, J. (1990). The Search for Modern China, London: Norton and Company.

Taylor, T. (1913). Opium: A Live Question. Contemporary Review, 10, 40-49.

Trachtenberg, M. (2006). The Craft of International History: A Guide to Method. Oxford: Princeton University Press.

Tosh, J. (2010). The Pursuit of History. Edinburgh: Pearson.

Turner, W.P.W. (1914). Report on a journey of investigation into the cultivation of the opium poppy in South Fukien. Jointly with officials appointed by the Chinese Government. In National Archives of the UK: FO 228/2458. 
UNDCP (United Nations Drug Control Programme). (2001). The impact of the Taliban prohibition on opium poppy cultivation in Afghanistan: A mission report. UNDCP.

Wakeman, F. (1977). The Fall of Imperial China, New York: Free Press.

Walker, W.O. (1991). Opium and Foreign Policy: The Anglo-American Search for Order in Asia, 1912-1954, Chapel Hill: University of North Carolina Press.

Wilkinson. (1910). Report by Consul-General Wilkinson Respecting the Suppression of Opium in Szechwan or the Period September 1909-March 1910. In National Archives of the UK: FO 881/9892.

Windle, J. (2011). Ominous Parallels and Optimistic Differences: Opium in China and Afghanistan. Law, Crime and History, 2(1), 141-164.

Windle, J. (2012). Insights for Contemporary Drug Policy: A Historical Account of Opium Control in India and Pakistan. Asian Journal of Criminology, 7(1), 55-74

Windle, J. (Forthcoming). Drug Prohibition as an Eastern Construct. Accepted for publication in International History Review.

Wright, M. (1968). China in Revolution: the First Phase, 1900-1913, London: Yale University Press.

Wyman, J. (2000). Opium and the State in Late-Qing Sichuan. In T. Brook \& B. Wakabayashi (Eds.), Opium Regimes: China, Britain, and Japan, 1839-1952, London: University of California Press.

Youngers, C.A. and Walsh, J.M. (2009). Development First: A More Humane and Promising Approach to Reducing Cultivation of Crops for Illicit Markets. Washington Office on Latin America.

Zhou, Y. (1999). Anti-Drug Crusades in Twentieth-Century China: Nationalism, History, and State Building, Oxford: Rowman \& Littlefield Publishers. 